\title{
EFEKTIVITAS KURIKULUM BERBASIS KEMASYARAKATAN
}

\section{EFFECTIVENESS OF CURRICULUM BASED ON COMMUNITY}

\author{
S Laeli1a, A Mahruddin', dan DF Fazriah ${ }^{2}$ \\ 1 Program Studi Manajemen Pendidikan Islam, Fakultas Keguruan dan Ilmu Pendidikan, \\ Universitas Djuanda Bogor, Jl. Tol Ciawi No. 1 Kotak Pos 35 Ciawi Bogor 16720 \\ 2 Program Studi Pendidikan Guru Sekolah Dasar, Fakultas Keguruan dan Ilmu Pendidikan, \\ Universitas Djuanda Bogor, Jl. Tol Ciawi No. 1 Kotak Pos 35 Ciawi Bogor 16720 \\ a Korespondensi: Sobrul Laeli, Email: obbunk@gmail.com \\ (Diterima: 07-06-2017; Ditelaah: 08-06-2017; Disetujui: 25-09-2017)
}

\begin{abstract}
The curriculum basically occupies a central position in the education process. This means that the curriculum is something very strategic to control the course of the education process. The curriculum directs all forms of educational activity and the achievement of educational goals. Community-based curriculum at Pondok Pesantren Darussyifa Al-Fithroh is coloring the activities of the subjects with social values such as on the subject of morals and fiqh. The purpose of this research is to know how far the effectiveness of community based curriculum in Pondok Pesantren Darussyifa Al-Fithroh Sukabumi. This research is a type of quantitative research with descriptive method with 89 respondents' santri alumni. The variable of this research is the effectiveness of Community Based Curriculum. Data collection techniques used observation methods, uninterrupted interviews, documentation and questionnaires. Test the validity of this study using expert opinion. The data analysis technique used quantitative descriptive statistical data with kai square formula. The results showed that the Effectiveness of Community Based Curriculum in Pondok Pesantren Darussyifa Al-Fithroh Sukabumi consisting of two subjects of akhlaq and fiqh subjects "effective". The effectiveness is obtained from kai square results obtained by price XO (observation X2O $=11.3818$. Results are then consulted on the criticism value of significant level X2t $5 \%=5.991$ with $\mathrm{dk}=2$ and this means $\mathrm{X} 20$ observations greater than $\mathrm{X} 2 \mathrm{t}$ at significant level 5\%. The null hypothesis that the community-based curriculum in Integrated Pesantren Darussyifa Al-Fithroh Sukabumi is ineffective is "rejected", while the alternative hypothesis which states that the communitybased curriculum at Pondok Pesantren Terladu Darussyifa Al-Fithroh Sukabumi is effectively "accepted." Porsentase based curriculum societal subjects on $89 \%$ effective subjects and on fiqh subjects $90 \%$ effective.
\end{abstract}

Keywords: curriculum, effectiveness, society.

\begin{abstract}
ABSTRAK
Tujuan penelitian ini untuk mengetahui sejauhmana efektivitas kurikulum berbasis kemasyarakatan di Pondok Pesantren Terpadu Darussyifa Al-Fithroh Sukabumi. Penelitian ini merupakan jenis penelitian kuantitatif dengan metode deskriptif dengan responden 89 santri alumni. Variabel penelitian ini adalah efektivitas kurikulum berbasis kemasyarakatan. Teknik pengumpulan data menggunakan metode observasi, wawancara tidak terstruktur, dokumentasi dan angket. Uji validitas penelitian ini menggunakan pendapat ahli. Teknik analisis data menggunakan data statistik deskriptif kuantitatif dengan rumus kai kuadrat. Hasil penelitian menunjukkan bahwa efektivitas kurikulum berbasis kemasyarakatan di Pondok Pesantren Terpadu Darussyifa Al-Fithroh Sukabumi yang terdiri dari dua cakupan mata pelajaran akhlaq dan fiqh "efektif". Keefektifan tersebut diperoleh dari hasil perhitungan
\end{abstract}


kai kuadrat yang diperoleh harga XO (observasi X20 =11,3818. Hasil ini kemudian dikonsultasikan pada nilai kritik taraf signifikan X2t 5\% =5,991 dengan dk $=2$ dan ini berarti X20 observasi lebih besar dari X2t pada taraf signifikan 5 \%. Hipotesis nihil yang menyatakan kurikulum berbasis kemasyarakatan tidak efektif "ditolak". Sedangkan hipotesis alternatif yang menyatakan kurikulum berbasis kemasyarakatan di Pondok Pesantren Terpadu Darussyifa Al-Fithroh Sukabumi efektif "diterima". Persentase kurikulum berbasis kemasyarakatan pada mata pelajaran akhlaq $89 \%$ efektif dan pada mata pelajaran fiqh $90 \%$ efektif.

Keywords: efektivitas, kurikulum, masyarakat.

Laeli S, A Mahruddin, dan DF Fazriah. 2017. Efektivitas kurikulum berbasis kemasyarakatan. Didaktika Tauhidi Jurnal Pendidikan Guru Sekolah Dasar 4(2): 115-125.

\section{PENDAHULUAN}

Pondok pesantren sebagai lembaga Islam yang memiliki tujuan mencetak generasi bangsa perlu mempertahankan eksistensinya sebagai sebuah lembaga pendidikan Islam yang masih memiliki ciri khas dan masih tradisional. Pesantren melakukan beberapa seleksi dalam menyeimbangi dengan dunia luar atau masyarakat, yang tidak jarang malah menawarkan pendekatan dalam nilai-nilai yang bertentangan dengan yang sudah digariskan pesantren. Akibatnya, terjadi semacam tarik-menarik kekuatan antara keduanya. Pemilahan kurikulum pondok pesantren, mempunyai makna yang sama secara bersama-sama akan secara total menghilangkan misi pesantren sebagai lembaga generasi ulama.

Pesantren mempunyai peran dan andil sangat besar dalam tersebar luasnya nilai agama pada saat ini. Tetapi faktanya nilai kekhasan pesantren dalam bentuk tradisional yang masih melekat membuat beberapa pesantren tidak bertahan lama pada saat ini. Tidak profesionalnya guru, kurang efektifnya kurikulum, metode yang diberikan pembelajaran yang masih tradisional. Semua menjadi pokok masalah yang menjadikan hilangnya misi pesantren.
Sistem pendidikan dengan berasrama menggunakan konsep pembinaan kurikulum Madrasah yang memiliki acuan Kementrian Agama ditambah dengan beberapa program lokal. Proses pendidikan nonformal ini memberi perhatian lebih dalam pembinaan karakter dan budi pekerti seluruh santri. Kurikulum yang disusun oleh pengelola pesantren berusaha mengintregrasikan nilai-nilai agama dalam kehidupan seharihari santri baik didalam lingkungan pesantren maupun di masyarakat.

Pondok Pesantren Darussyifa Al-Fithroh sebagai objek kajian penelitian, karena sebagai lembaga pendidikan nonformal yang memiliki keunikan tersendiri dalam bidang pelaksanaan kurikulum dengan berbagai substansi dalam pembelajaran yang sangat beragam. Kurikulum yang diterapkan ini didampingi dengan manajemen yang baik pula. Manajemen kurikulum perlu ditinjau dan di evaluasi bagaimana pelaksanaannya terkait dalam pendidikan dan dinilai tingkat keberhasilannya, tidak hanya pendidikan formal saja tetapi pendidikan non formal dan salah satu pesantren dari komponen kurikulum tujuan, isi, metode dan evaluasi. Evaluasi kurikulum yaitu bagaimana mengukur keefektifan penerapan kurikulum yang ada di Pondok Pesantren Terpadu Darussyifa Al-Fithroh pada dua mata ajar yakni akhlak dan fiqh. 


\section{MATERI DAN METODE}

\section{Materi}

\section{Efektivitas}

Wahyudi (2012) berpendapat bahwa efektivitas dalam pendidikan dapat ditinjau dari sudut prestasi, yaitu mampu menghasilkan tamatan yang berkualitas dalam arti mampu bersaing di pasaran kerja, ada hubungan antara ilmu yang didapat dengan kebutuhan dalam membangun, serta mempunyai nilai ekonomis yang tinggi sesuai dengan pendidikan terakhir yang diperoleh. Efektivitas dari segi proses pendidikan memiliki semangat dan motivasi belajar yang tinggi peserta didik.

Sedangkan Ridwan (2014) berpendapat bahwa efektif bukan semata-mata efektivitas untuk pencapaian tujuan, yakni berupa hasilhasil yang diperoleh siswa. dia bukan pula arti semata-mata untuk efektivitas program yang dilaksanakan, dengan mengabaikan prosesnya.

Martoyo (2002) berpendapat bahwa efektivitas sebagai suatu kondisi dimana ketika memilih tujuan yang ingin dicapai dan saran atau peralatan yang digunakan, diikuti dengan pengetahuan dalam diri dikatakan tepat, sehingga apa yang menjadi tujuan bisa tercapai dengan hasil yang memuaskan.

Prinsip Pengembangan Kurikulum diantaranya adalah efektivitas. Efektivitas disini di artikan adalah dalam merencanakan kegiatah harus memikirkan sejauhmana efektivitas atau yang diinginkan dan ketahui berkenaan terhadap kegiatan yang dapat terlaksana atau tercapai.

Efektivitas di sini diartikan yaitu menjalankan suatu pekerjaan yang benar, efektivitas berarti bagaimana menguji sejauh kemampuan untuk memilih sasaran yang tepat. Dalam halnya efektivitas manajer adalah yang memilih pekerjaan dalam bidangnya dan mengetahui cara yang dalam menjalankannya.

\section{Kurikulum Berbasis Kemasyarakatan}

Rusman (2012) berpendapat kurikulum adalah pembelajaran dari pengalaman yang telah direncanakan dalam mempersiapkan kegiatan siswa untuk mencapai tujuan dalam pendidikan yang diinginkan.

Pengertian kurikulum yang lebih luas yaitu dalam semua kegiatan pembelajaran dan pengalaman serta semua yang berpengaruh terhadap bentuk kepribadian perilaku peserta didik, baik ketika di sekolah maupun ketika diluar sekolah dan dapat dipertanggung jawabkan oleh pihak sekolah untuk mencapai semua tujuan pendidikan. Segala sesuatu disini merupakan hidden curriculum, misalnya fasilitas dan sarana prasarana, lingkungan yang begitu nyaman dan berbunga, suasana keakraban, kerja sama yang harmonis dan saling mendorong dalam proses kegiatan pembelajaran serta media sumber kegiatan belajar yang memadai.

Landasan Kurikulum dalam Al-Quran

Surah Al-Ikhlas

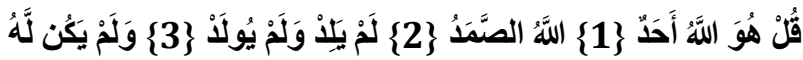

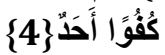

Artinya: Katakanlah (wahai Muhammad) bahwa Allah yang Maha Esa." Allah merupakan tempat bergantung dari segala sesuatu yang ada di alam semesta. Dia Allah tidak beranak dan juga tidak diperanakkan, bahwa tidak ada seorang (atau makhluk) pun yang setara (sebanding) dengan-Nya. (Q.S AlIkhlas : 114:1-4)

Ayat Al-Qur'an diatas menjelaskan bahwa kerangka dasar sebagai pedoman operasional dalam menyusun rancangan pembuatan kurikulum pendidikan Islam. Kerangka tersebut adalah tauhid yang menjadi kurikulum inti pendidikan Islam 
dan harus dimantapkan sebagai unsur pokok yang tidak dapat dirubah. Banyak makna dalam mencapai tujuan pendidikan agama islam salah satunya yaitu diperlukan kurikulum untuk menyesuaikan dengan beberapa tujuan dalam pendidikan Islam dan menempatkan sesuai dengan tingkatan usia, tingkat perkembangan dalam kejiwaan anak dan kemampuan, kecakapan, kedewasaan dalam belajar.

Adapun pandangan lain terhadap pendidikan untuk masyarakat harus disesuaikan artinya masyarakat dilibatkan dalam semua kegiatan atau program yang telah direncanakan untuk menjawab dari setiap kebutuhan mereka. Secara singkat dikatakan, masyarakat perlu diberdayakan, diberi peluang dan kebebasan untuk mendesain, merencanakan, membiayai, mengelola dan menilai sendiri apa yang diperlukan secara spesifik di dalam, untuk dan oleh masyarakat sendiri

\section{Metode}

Metode penelitian dalam penelitian ini ialah deskritif dengan kata lain melalui pendekatan kuantitatif. Yang di maksud dengan metode deskriptif ialah metode dengan melakukan penelitian dalam status sekelompok manusia kemudian, objek, set kondisi, sistem pemikiran, ataupun dalam suatu kelas sering terjadi peristiwaperistiwa yang kurang baik pada zaman sekarang. Tujuan dari penelitian ini yaitu untuk membuat suatu deskripsi atau gambaran beberapa fakta, sifat-sifat dan hubungan antara fenomena terjadi dan yang sedang diselidiki (Nazir 2005).

Dalam penelitiannya para peneliti menggunakan dengan metode deskripsi ini karena rumusan masalah yang sering terjadi berkenaan dengan pertanyaan terhadap variabel mandiri, baik hanya satu variabel atau lebih (variabel yang berdiri sendiri).
Jadi dalam penelitian yang dilakukan oleh peneliti tidak membuat beberapa perbandingan variabel itu dengan sampel lain, dan mencari adanya hubungan variabel itu dengan variable yang lainnya (Sugiyono 2006).

Dalalm pelaksanaan metode penelitian yang menggunakan kuantitatif ialah metode penelitian yang memiliki landasan filsafat positivisme, dan digunakan dalam meneliti populasi dan sampel tertentu, pengumpulan untuk beberapa data yaitu menggunakan instrumen dalam penelitian, dan analisis data yaitu bersifat kuantitatif atau statistik, dengan memiliki tujuan untuk menguji dan menyimpulkan yang sudah ditetapkan.

\section{Teknik Pengumpulan Data}

Untuk menemukan data yang akurat, diperlukan teknik pengumpulan data untuk yang memiliki validitas tinggi, sehingga mampu mengungkapkan permaslahan yang diteliti.

\section{Observasi Terstruktur}

Bagian dari observasi terstruktur ialah observasi yang sudah direncanakan secara baik dan sistematis, tentang nantinya apa saja yang akan diamati, kapan waktunya yang tepat dan dimana tempatnya. Teknik ini digunakan untuk mengetahui keadaan dan kondisi di Pesantren Terpadu Darussyifa AlFithroh Sukabumi, baik sarana prasarana, struktur organisasi, proses pembelajaran, keadaan guru dan murid yang terkait erat dengan penelitian yang dilakukan.

\section{Wawancara Tidak Terstruktur}

Wawancara tidak terstruktur adalah wawancara dimana peneliti melakukan penelitiannya dengan bebas dan tidak menggunakan secara sistematis tentang pedoman-pedoman wawancara yang lengkap untuk pengambilan datanya. Dan pedoman dilakukan dalam wawancaranya 
hanya menggunakan beberapa garis-besar permasalahannya yang nantinya akan dpertanyakan.

\section{Dokumentasi}

Dokumentasi adalah pengumpulan, penelitian, pengolahan, penyimpanan berupa informasi untuk menyempurnakan bidang pengetahuan, pemberitahuan atau pengumpulan dari bukti-bukti atau keterangan. Teknik ini biasanya digunakan dalam pengumpulan data yang berhubungan dengan dokumen tentang santri, proses pembelajaran, dan lain-lain yang nantinya dapat membantu atau mendukung penelitian ini.

\section{Kuesioner (Angket)}

Kuesioner bagian dari teknik pengumpulan beberapa data yang nantinya menggunakan atau memberikan seperangkat pernyataan atau pertanyaan secara tertulis untuk diberikan kepada responden untuk dijawabnya. Teknik ini digunakan untuk mengetahui dan mengukur sejauhmana efektivitas kurikulum berbasis kemasyarakatan di Pondok Pesantren Terpadu Darussyifa Al-Fithroh Sukabumi, (angket terlampir).

\section{Skala Likert}

Penelitian ini mengukur efektivitas kurikulum berbasis kemasyarakatan. Skala likert dipergunakan untuk menguji dan mengukur bagian pembelajaran yang biasanya lebih efektif. Biasanya skala likert menggunakan beberapa variabel yang nantinya dapat diukur dan diperluas menjadi beberapa indikator variabel. Yang nantinya indikator-indikator tersebut dapat dijadikan sebagai acuan untuk menyusun instrumen yang berupa pernyataan-pernyataan atau pertanyaan.

\section{Teknik Analisis Data}

Dalam analisis data yang sering digunakan dalam pelaksanaan penelitian ini ialah teknik dari analisis data komparasi yang bertujuan untuk membandingkan efektivitas kurikulum berbasis kemasyarakatan di Pesantren Terpadu Darussyifa Al-Fithroh pada kelas mubtadi.

\section{HASIL DAN PEMBAHASAN}

\section{Hasil}

\section{Efektivitas Kurikulum Berbasis Kemasyarakatan}

Kurikulum yang berbasis pada masyarakat adalah kurikulum yang memakai perpaduan dari pondok pesantren itu sendiri dan di gabung dengan masyarakat agar tercapainya tujuan pengajaran. Kurikulum ini memiliki tujuan untuk meperkenalkan santri terhadap lingkungannya, membekali santri kemampuan dan keterampilan yang dapat menjadikan dalam dirinya suatu bekal hidup bagi mereka untuk di gunakan di masyarakat, dan membekali santri supaya bisa jauh lebih hidup secara mandiri. Bahan objek kajiannya yaitu ketetapan yang biasanya dilakukan oleh daerah, dan disesuaikan dengan lingkungan alam dan kodisi di wilayah tersebut serta diperhatikan juga, ekonominya, social, dan budaya agar dapat disesuaikan dalam pembangunan daerah agar dapat dipelajari dengan mudah oleh siswa di daerah tersebut.

Menurut teori berbasis masyarakat, titik awal penentu dalam pembentukan kurikulum yaitu tingkat sosial. Para ahli berbeda pendapat diantara mereka sendiri mengenai lembaga pendidikan harus berdasarkan kepada level sosial yang sudah ada. Nantinya mereka dapat dikategorikan berdasarkan beberapa faktor berikut. 
1. Konformis, artinya mempercayai bahwa pelevelan di masyarakat yang ada saat ini merupakan yang terbaik.

2. Reformis, artinya beranggapan bahwa masyarakat yang memiliki suara yang paling utama dalam pembentukan struktur yang demokratis bagi mereka. Tetapi, masih memiliki keinginan suatu reformasi yang utama di dalam tingkat sosial. Penentu dari keberhasilannya ialah kurikulum.

3. Futuris. Artinya jauh melihat beberapa tahun yang akan datang dari pada hanya terpaku pada masalah-masalah. Mereka membuat analisa dari perkembangan pada saat ini dan memprediksi dari beberapa data yang ada yang memiliki skenario alternatif dan mereka menanggapi bahwa pilihan yang dimiliki orang-orang dalam pembentukan beberapa tahun yang akan datang serta menguatkan diri dan memberikan motivasi kepada sekolah untuk memberikan kepada peserta didik alat dalam membentuk kepribadian yang lebih baik dan bisa menata kehidupan di masa yang akan datang.

4. Radikalis artinya berpendapat bahwa masyarakat bagian dari yang dan setuju bahwasanya kurikulum yang gagal, mereka akan menunjukan beberapa kekurangan tersebut kemudian memperkuat anak muda dan di pengaruhi dengan perubahan radikal. Nantinya efeknya munculah pandangan yang neo marxis, mereka mempercayai bahwa masalah yang terjadi saat ini ialah hanyalah gejala. Gejala yang dimaksudkan adalah ketidakadilan dalam sosial yang memberikan pengaruh dalam kapitalis teknologi.

\section{Keunggulan dari Kurikulum Berbasis Masyarakat}

1. Kurikulum yang sesuai dengan apa yang dibutuhkan dan dapat dikembangkan oleh masyarakat;

2. Kurikulum dapat sesuai dengan kebutuhan dan memiliki tingkatan serta dapat diseimbangkan dengan kemampuan sekolah, baik secara finansial, manajerial, dan dapar berjalan secara profesional.

3. Perencanaan kurikulum terlaksana oleh guru-guru sendiri dan dapat mempermudah dalam pelaksanaannya;

4. Adanya motivasi pimpinan khusus kepada guru atau wali kelas untuk mengembangkan potensi diri, serta mencari dan menciptakan sesuatu yang baru khususnya dibidang kurikulum yang sebaik-baiknya, sehingga membuat para guru berkompetensi dalam pengembangan kurikulum.

\section{Penyajian, Pengolahan, Interpretasi Data dan Analisis Pengembangan}

\section{Penyajian Data}

Penyajian data pada penelitian ini diperoleh dari data responden diambil dari data hasil angket. Data responden adalah data yang di hasilkan dari penelitian di Pesantren Terpadu Darussyifa Al-Fithroh, sedangkan yang menjadi responden adalah alumni santri SMA Plus lulusan tahun ajaran 2015/ 2016 yang berjumlah 89 orang. Manfaat digunakan data responden untuk melengkapi suatu kebutuhan peneliti dalam menentukan efektif atau tidaknya kurikulum berbasis kemasyarakatan yang dipergunakan oleh pesantren dalam mata pelajaran kajian-kajian kitab kuning akhlaq dan fiqh. 
Hasil data angket masih merupakan skor mentah, sehingga dibutuhkan pengelolaan skor yang masih mentah berubah menjadi skor perolehan. Seluruh angket yang nantinya diberikan kepada alumni terdiri dari 20 soal yang meliputi dua indikator dan aspek penilaian menjadi sesuai dengan apa yang menjadi tujuan materi kajian akhlaq dan fiqh dalam kitab akhlaq lilbanat/ banin, ta'limul muta'alim, safinatunnajah dan Riyadhul Badi'ah. Hal ini dimaksudkan untuk mengukur dan mengetahui sejauhmana efektivitas kurikulum berbasis kemasyarakatan yang dipergunakan oleh pesantren dalam mengajarkan materi. Apakah kurikulum sudah berjalan sesuai dengan keefektifanya dan dapat menyesuaikan dengan tujuan kurikulum yang diharapkan atau tidak.

Berdasarkan cakupannya dalam pembelajaran yang telah disusun dalam kurikulum berbasis kemasyarakatan di Pesantren Terpadu Darussyifa Al-Fithroh. Cakupan pembelajaran tersebut antara lain akhlaq dan fikih. Berikut pemaparan lebih jelas mengenai cakupan pembelajaran akhlaq dan fikih.

\section{a. Akhlaq}

Kelompok mata pelajaran akhlak ini dimaksdukan untuk membentuk akhlak santri yang mampu menjadi pribadi islami, penguatan ibadah yang perlu dilakukan, bermusyawarah, di mana santri diajarkan untuk menyerahkan diri di hadapan Allah Swt, bagaimana akhlak kepada Allah SWT, akhlak kepada nabi Muhammad SAW, akhlak terhadap sesama manusia, akhlak untuk diri sendiri, dan akhlak terhadap lingkungan. Kajian kitab yang pakai untuk menemukan indikator ini adalah kajian kitab Akhlaq Lilbanat dan Ta'limul Muta'alim b. Fikih

Dalam mata pelajaran atau pembahasan fikih dimaksudkan untuk mempelajari hukum atau kajian Islam yang berkaitan dengan kehidupan manusia, untuk dapat di perdalam dari segi pengetahuan dan hukum agama baik secara aqidah, akhlak ataupun dalam bidang ibadah dan muamalah. Kajian kitab yang di pakai untuk mencari indikator ini adalah kajian kitab safinatunnajah dan kitab Riyadhul Badi'ah.

\section{Pengolahan Data}

Dalam pengolahan data ini, peneliti mencoba menggunakan rumus kai kuadrat yang diperuntukan untuk menguji dan membandingkan efektivitas kurikulum berbasis kemasyarakatan yang digunakan di Pesantren Terpadu Darussyifa Al-Fithroh.

Adapun hasil pengujian terhadap efektivitas kurikulum berbasis kemasyarakatan yang digunakan di Pondok Pesantren Terpadu Darussyifa Al-Fithroh diuraikan pada Tabel 1.

Tabel 1 Pengujian terhadap efektivitas kurikulum

\begin{tabular}{llrrrr}
\hline No Penilaian & Efektif & $\begin{array}{c}\text { Kurang } \\
\text { Efektif }\end{array}$ & $\begin{array}{c}\text { Tidak } \\
\text { Efektif }\end{array}$ & Total \\
\hline $1 \quad$ Akhlaq & 67 & 10 & 12 & 89 \\
$2 \quad$ Fiqh & 53 & 29 & 7 & 89 \\
Total & 120 & 39 & 19 & 178 \\
\hline
\end{tabular}

Efektivitas

Kurikulum

Berbasis

Kemasyarakatan di Pesantren Terpadu Darussyifa Al-Fithroh diuraikan pada Tabel 2.

Rumus yang digunakan:

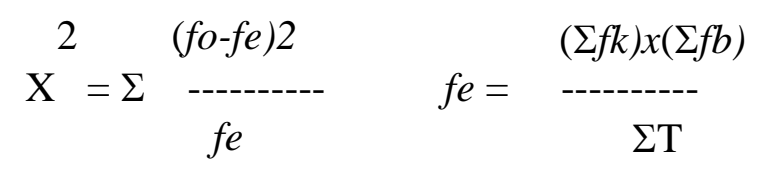

Sumber: Ridwan dan Sunarto (2007) 
Tabel 2 Hasil studi lapangan tentang efektivitas kurikulum berbasis kemasyarakatan di Pesantren Terpadu Darussyifa Al-Fithroh

\begin{tabular}{|c|c|c|c|c|c|}
\hline \multirow[b]{2}{*}{ Sel } & \multicolumn{3}{|c|}{$(\Sigma f k) x(\Sigma f b)$} & \multirow[b]{2}{*}{$(f o-f e)^{2}$} & \\
\hline & Fo & 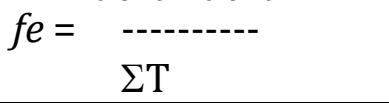 & fo-fe & & \\
\hline 1 & 67 & $120 \times 89 / 178=60$ & -7 & 49 & 0,8667 \\
\hline 2 & 10 & $39 \times 89 / 178=19,5$ & $-8,5$ & 72,25 & 3,7533 \\
\hline 3 & 12 & $19 \times 89 / 178=9,5$ & 2,5 & 6,25 & 0,6579 \\
\hline 4 & 53 & $120 \times 89 / 178=60$ & -7 & 49 & 0,8167 \\
\hline 5 & 29 & $39 \times 89 / 178=19,5$ & 9,5 & 90,25 & 4,6283 \\
\hline 6 & 7 & $19 \times 89 / 178=9,5$ & $-2,5$ & 6,25 & 0,6579 \\
\hline Total & 178 & $178=\mathrm{N}$ & & & $\begin{array}{r}11,3818 \\
X^{2}{ }_{0}\end{array}$ \\
\hline
\end{tabular}

$\mathrm{dk}=(\mathrm{k}-1) \cdot(\mathrm{b}-1)$

$\mathrm{dk}=(3-1) \cdot(2-1)$

$\mathrm{dk}=2.1=2$

Hasil dari perhitungan di atas menunjukkan bahwa harga $\mathrm{x}^{2}$ o adalah 11,3818. Maka berdasarkan tabel kai kuadrat taraf signifikan 5\% dengan $\mathrm{dk}=2$, menghasilkan kesimpulan seperti yang ditunjukkan Tabel 3.

Tabel 3 Kai kuadrat

\begin{tabular}{crc}
\hline $\begin{array}{c}\text { Harga } \\
\mathrm{x}^{2}{ }_{0}\end{array}$ & $\begin{array}{c}\text { Taraf begitu } \\
\text { Signifikan 5\% }\end{array}$ & Kesimpulan \\
\hline 11,3818 & 5,991 & $11,3818>5,991$ \\
\hline
\end{tabular}

\section{Analisis Interpretasi Data}

Hasil perhitungan diatas harga $\mathrm{x}^{2}{ }_{\mathrm{o}}=11,3818$, dengan memperhitungkan terlebih dahulu degree of freedom (df) atas derajat keberhasilannya (dk) seperti yang didapatkan pada Tabel 3 pada tabel tersebut mempunyai kolom 3 buah dan dengan baris 2.

Dengan demikian, dk yang dicari disini ialah sama dengan adanya hasil antara perkalian banyaknya lajur yang terdapat dalam tabel perhitungan yang dikurangi 1 , yaitu (b-1), atau singkatnya $d k=(k-1)(b-1)$, atau singkatnya $\mathrm{dk}=(\mathrm{k}-1)(\mathrm{b}-1)$ atau $(3-1)(2-1)=2$.
Pengurangan 1 dari beberapa jumlah kolom dan jumlah baris yang didapatkan pada tabel itu adalah disebabkan adanya kebebasan yang terbatas dalam mengisi angka baris yang terakhir sesudah adanya kolom dan baris lain yang terisi. Jadi, sesudah (k-1) atau (b-1) terisi, tidak ditemukan lagi kebebasan untuk kolom ataupun baris terakhir, karena jumlah menurut baris itu telah tertentu. Dengan $\mathrm{dk}=16$, maka diperoleh harga kritik kai kuadrat dengan tabel nilai kai kuadrat dengan taraf yang begitu signifikan $5 \%$ adalah 5,991 .

Perbandingan harga kritik $\left(\mathrm{x}^{2}{ }_{0}=11,3818\right)$ terhadap (taraf signifikansi $5 \%=5,991$ ) adalah lebih besar $(11,3818>5,991)$. Dari hasil perbandingan tersebut, didapatkan kesimpulan bahwa hipotesis nilai $\left(\mathrm{H}_{\mathrm{o}}\right)$ dapat dikatakan kurikulum berbasis kemasyarakatan tidak efektif "ditolak", karena adanya perbedaan yang begitu signifikan dari frekuensi yang diobservasi dengan frekuensi teoritik. Dengan demikian, hipotesis dari alternatif lain ialah $\left(\mathrm{H}_{\mathrm{a}}\right)$ menyatakan bahwa kurikulum yang berbasis kemasyarakatan efektif "diterima".

Berdasarkan hasil angket yang telah dikorelasikan dengan indikator efektivitas kurikulum berbasis kemasyarakatan di Pesantren Terpadu Darussyifa Al-Fithroh diuraikan pada Tabel 4 . 
Tabel 4 Hasil angket

\begin{tabular}{llrrr}
\hline No & Penilaian & Efektif & $\begin{array}{c}\text { Kurang } \\
\text { Efektif }\end{array}$ & $\begin{array}{c}\text { Tidak } \\
\text { Efektif }\end{array}$ \\
\hline 1 & Akhlaq & 67 & 10 & 12 \\
2 & Fiqh & 53 & 29 & 7 \\
\hline
\end{tabular}

Dari tabel 4 didapatkan kesimpulan bahwa kurikulum yang berbasis kemasyarakatan yang efektif ialah dari pembelajaran akhlaq. Hal ini dikarenakan mata pelajaran akhlaq lebih diminati santri dan berdampak terhadap perilaku santri dalam mengaplikasikanya dikehidupan sehari-hari. Sedangkan mata pelajaran bagi santri butuh pemahaman begitu mendalam dan tidak cukup dengan waktu sebentar.

\section{Analisis Pengembangan}

Penelitian ini menunjukan bahwasanya kurikulum berbasis kemasyarakatan di Pesantren Terpadu Darussyifa AL-Fithrh efektif, hal ini terbukti dari hasil uji hipotesis $\mathrm{x}^{2}$ o sebesar 11,3818. Angka kolerasi ini lebih besar dibandingkan dengan $\mathrm{x}^{2} \mathrm{t}$ pada taraf yang begitu signifikan $5 \%=5,991$. Hasil uji hipotesis ini memberikan makna bahwa terdapat keefektifan kurikulum berbasis kemasyarakatan di Pesantren Terpadu Darussyifa Al-Fithroh.

Efektivitas kurikulum berbasis kemasyarakatan di Pesantren Terpadu Darussyifa Al-Fithroh, dapat dinilai ketepatan pengunaan tujuan kurikulum. Ketepatan kurikulum dan tercapainya beberapa tujuan pembelajaran tersebut dapat dibuktikan dari beberapa hasil angket.

Selain itu faktor-faktor pendukung terkait dengan efektivitas kurikulum berbasis kemasyarakatan di Pesantren Terpadu Darussyifa Al-Fithroh dapat dinilai dari beberapa faktor berikut.

a. Kehadiran guru yang selalu berada dikelas sesuai jadwal yang telah ditentukan. b. Adanya penyeleksian bagi tenaga pendidik yang diseleksi dari faktor kemampuannya dalam bidang agama.

Dukungan dari faktor-faktor yang telah disebutkan di atas, dapat memberikan pengaruh positif dalam meningkatkan keefektifan kurikulum berbasis kemasyarakatan di Pesantren Terpadu Darussyifa Al-Fithroh.

Faktor terpenting dalam meningkatkan efektivitas kurikulum berbasis kemasyarakatan di Pesantren Terpadu Darussyifa Al-Fithroh adalah kemampuan guru. Karena sebaik apapun metode atau bentuk kurikulum tidak akan berjalan secara efektif, jika guru ataupun pengelola Pondok tidak melaksanakan program atau melaksanakan pembelajaran dengan baik.

\section{Pembahasan}

Pendirian lembaga atau Yayasan Sosial dan Pendidikan Islam Darussyifa Al-Fitrat dilandasi keinginan yang begitu tinggi dengan tekat yang begitu kuat ingin memadukan sistem pendidikan pesantren yang hanya memilik orientasi pada pengembangan potensi-potensi ruhaniah manusia dengan pendidikan umum yang berorientasi kepada pengembangan kecerdasan pikiran dan keterampilan.

Perpaduan bagi keduanya dapat diharapkan menemukan hasil dari cakrawala baru khususnya bagi bidang pendidikan di Indonesia yaitu antara fikir atau amal (kecerdasan hingga keterampilan) dapat bersatu dengan zikir (kognitif, konatif dan psikomotor) yang dapat berjalan dengan seimbang sehingga didapatkan atau menghasilkan lulusan kreatif yang memiliki keseimbangan pada diri dan memiliki beberapa aspek jasmani dan rohani, pengetahuan, keterampilan dan akhlak. Yang kemudian ditunjang oleh keahlian dalam 
mengelola secara teknis suatu kegiatan usaha.

Salah satu upaya terwujudnya kerangka pemikiran tersebut di atas, yaitu dengan adanya lembaga pendidikan sosial yang berbasis pendidikan dan kepesantrenan. Pondok pesantren ialah suatu lembaga pendidikan yang memiliki khas atau ciri yaitu keislaman yang paling menonjol yang memiliki daya tarik, khususnya bagi insan atau praktisi pendidikan atau cendikiawan bagi pimpinan umat. Ketika berbicara pondok pesantren, kita langsung dapat mengetahui dan mengerti dari peran, fungsi, dan kontribusi bagi pondok pesantren sebagai jembatan menuju lembaga pendidikan keislaman dan wadah bagi pendakwah Islam dalam mewujudkan masyarakat madani.

\section{Makna dan Tujuan Bagi Kurikulum Berbasis Masyarakat}

KBM atau Kurikulum Berbasis Masyarakat adalah kurikulum yang memiliki perpaduan antara sekolah dan masyarakat. Alasannya untuk menemukan dan mencapai tujuan pengajaran. Kurikulum memiliki tujuan untuk memperkenalkan santri terhadap lingkungannya, membekali santri kemampuan dan keterampilan yang nantinya dapat dijadikan bekal hidup mereka di masyarakat, dan membekali santri agar bisa lebih hidup mandiri. Bahan objek kajiannya yaitu kebijakan serta ketetapan yang mengaitkan di daerah, serta disesuaikan dengan bagaimana kondisi lingkungan dan alamnya, kemudian sosial, ekonomi, serta budaya yang diharapkan dengan kebutuhan pembangunan bagi daerah yang nantinya dapat dipelajari oleh peserta didik di daerah tersebut.

Menurut teori berbasis masyarakat, titik awal penentu dari yang paling utama ialah kurikulum yaitu tingkat sosial. Para ahli berbeda pendapat diantara mereka sendiri mengenai lembaga pendidikan harus mendasarkan diri pada level sosial yang ada.

Adapun kegiatan santri dan guru, kegiatan siswa mestinya mempertimbangkan pemberian peluang bagi santri untuk mencari, mengolah, dan menemukan sendiri pengetahuan, di bawah bimbingan guru. Guru dalam kurikulum yang berbasis masyarakat berperan sebagai fasilitator, sumber belajar, pembina, konsultan, sebagai mitra kerja yang memfasilitasi siswa dalam pembelajaran

\section{KESIMPULAN DAN IMPLIKASI}

\section{Kesimpulan}

Berdasarkan hasil penelitian menunjukkan bahwa kurikulum yang berbasis kemasyarakatan di Pondok Pesantren Darussyifa Al-Fithroh Sukabumi efektif. Keefektifan kurikulum tersebut diperoleh beberapa hasil dari perhitungan kai kuadrat yang diperoleh harga $\mathrm{X}_{0}$ (observasi $\mathrm{X}^{2} \mathrm{O}$ $=11,3818$. Hasil ini kemudian dikonsultasikan pada nilai kritik taraf begitu signifikan $\mathrm{X}^{2 \mathrm{t}} 5 \%=5,991$ dengan $\mathrm{dk}=2$ dan ini berarti $\mathrm{X}^{2} \mathrm{O}$ observasi lebih besar dari $\mathrm{X}^{2 \mathrm{t}}$ pada taraf signifikan 5\%. Hipotesis nihil yang menyatakan kurikulum berbasis kemasyarakatan di Pesantren Terpadu Darussyifa Al-Fithroh Sukabumi tidak efektif "ditolak".

Sementara itu, hipotesis alternatif yang menyatakan kurikulum berbasis kemayarakatan di Pesantren Terpadu Darussyifa Al-Fithroh Sukabumi efektif "diterima". Persentase kurikulum berbasis kemasyarakatan dalam mata pelajaran akhlaq 89\% efektif dan dalam mata pelajaran fikih $90 \%$ efektif. 


\section{Implikasi}

Bahwa keutuhan nilai pesantren perlu dijaga tidak hanya menerapkan metode tradisional dalam sistem pengelolaannya tetapi butuh manajemen yang baik untuk mengimbanginya sesuai perkembangan zaman saat ini. Terlebih dalam aplikasi kurikulum. Melalui acuan Kementrian Agama dan Kementrian Pendidikan dan Kebudayaan maka pesantren pun perlu membentuk inovasi kurikulum tersendiri dapat disesuaikan dengan tujuan pesantren didirikan serta dapat disesuaikan dengan budaya awal pesantren.

Halnya Darussyifa Al-Fithroh disamping kurikulum wajib yang digunakan, pondok inipun memiliki empat dimensi kurikulum yakni kurikulum berbasis keterpaduan, kurikulum berbasis kompetensi, kurikulum berbasis kemasyarakatan dan kurikulum berbasis amaliyah ubudiyyah sebagai bentuk strategi terwujudnya pondok sebagai pencetak Ulama'ul Amiliin.

\section{DAFTAR PUSTAKA}

Nazir M. 2005. Metode penelitian. Ghalia Indonesia, Bogor.

Martoyo. 2002. Manajemen sumber daya manusia. BPFE, Yogyakarta.

Republik Indonesia. 2004. Mushaf Al-Quran Terjemah, Kementrian Agama RI. Sekretariat Negara, Jakarta.

Ridwan. 2014. Penanganan efektif bimbingan dan konseling di sekolah. Pustaka Pelajar, Yogyakarta.

Ridwan dan Sunarto. 2007. Pengantar statistika dan penelitian pendidikan, sosial, ekonomi, komunikasi, dan bisnis. Alfa Beta, Bandung.

Rusman. 2012. Manajemen kurikulum. PT Raja Grafindo Persada, Depok.

Sugiyono. 2006. Metode penelitian kuantitatif, kualitatif, dan R\&D. Alfa Beta, Bandung.

Wahyudi. 2012. Kepemimpinan kepala sekolah dalam organisasi pembelajar. Alfa Beta, Bandung. 